\title{
Constructing collective identities and solidarity in premiers' early speeches on COVID-19: a global perspective
}

\author{
Martina Berrocal (1) ${ }^{1 凶}$, Michael Kranert (10 2 , Paola Attolino ${ }^{3}$, Júlio Antonio Bonatti Santos ${ }^{4}$, \\ Sara Garcia Santamaria ${ }^{5}$, Nancy Henaku ${ }^{6}$, Aimée Danielle Lezou Koffi ${ }^{7}$, Camilla Marziani (iD ${ }^{8}$, \\ Viktorija Mažeikienè ${ }^{9}$, Dasniel Olivera Pérez ${ }^{10}$, Kumaran Rajandran ${ }^{11}$ \& Aleksandra Salamurović ${ }^{12}$
}

The COVID-19 pandemic has prompted a unique global experience, arousing both exclusionary nationalistic and inclusionary responses of solidarity. This article aims to explore the discursive and linguistic means by which the COVID-19 pandemic, as a macro-event, has been translated into local micro-events. The analysis studies the global pandemic through the initial statements of 29 leading political actors across four continents. The aim is to examine discursive constructions of solidarity and nationalism through the social representation of inclusion/exclusion of in-, out-, and affiliated groups. The comparative analysis is based on the theoretical and methodological framework of the socio-cognitive approach to critical discourse analysis and is informed by argumentation theory and nationalism studies. The results of our analysis suggest that leaders have constructed the virus as the main outgroup through the metaphors of the pandemic-as-war and the pandemic-as-movement which have entered the national space. Faced with this threat, these speeches have discursively constructed the nation-as-a-team as the main in-group and prioritized (1) a vertical type of solidarity based on nationhood and according to governmental plans; (2) exclusionary solidarity against rule-breakers; (3) horizontal solidarity that is both intergenerational and among family members, and (4) transnational solidarity. It is not by chance that the world stands as a relevant affiliated group that needs to forcibly collaborate in order to face the main outgroup, the virus itself. A major consensus has been found in constructing the out-group. In contrast, the linguistic and discursive constructions of in-groups and their affiliates display a greater variation, depending upon the prevalent discursive practices and social context within different countries.

\footnotetext{
${ }^{1}$ Friedrich Schiller University, Jena, Germany. ${ }^{2}$ University of Southhampton, Southhampton, United Kingdom. ${ }^{3}$ University of Salerno, Salerno, Italy. ${ }^{4}$ Federal University of São Carlos, São Carlos, Brazil. ${ }^{5}$ Universitat Jaume Castelló, Castelló, Spain. ${ }^{6}$ Michigan Technological University, Michigan, USA. ${ }^{7}$ Université Félix Houphouët-Boigny, Côte d'Ivoire, Ivory Coast. ${ }^{8}$ University of Bologna, Bologna, Italy. ${ }^{9}$ Mykolas Romeris University Vilnius, Vilnius, Lithuania.

10 University of Havana, Havana, Cuba. ${ }^{11}$ School of Humanities, Universiti Sains Malaysia, George Town, Malaysia. ${ }^{12}$ Friedrich Schiller University,

Jena, Germany. ${ }^{凶}$ email: martina.berrocal@uni-jena.de
} 


\section{Introduction}

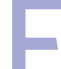
pidemics and pandemics are perennial transnational phenomena, as they had always spread through the increasingly interconnected world along with the networks of trade and travel (Malm, 2020; Huber, 2020). In the COVID-19 pandemic, however, this trend was realized on an unprecedented scale: the spread of the virus affected nearly everybody and led to a 'unique shared experience' (Bieber, 2020a, p. 1) because of the almost simultaneous worldwide reaction of lockdowns and shutdowns. This distinguishes it from other seemingly 'global' phenomena, such as the financial crisis or previous epidemics which were confined to one or more regions (e.g., Ebola, SARS, Zika). Within three months, the pandemic developed from a Chinese public health issue into a global health crisis.

The COVID-19 crisis is regarded as 'a textbook example of contemporary globalization processes' (Blommaert, 2020), with diseases spreading along with the mobile networks of the land, sea, and air travel which facilitate globalization (see also Malm, 2020). However, one of the most salient features common to most countries in the very first phase of the outbreak was the nation-oriented reactions (e.g., closure of borders, restrictions of medical and social aid within state borders), which challenged the concept of global solidarity. These circumstances have made nationalism, in all its nuances, an important concept in the discourse of the pandemic. Notably, the concept of solidarity itself has become prominent, both as opposed and linked to nationalism, and/or as a feature of renewed global interrelations. Given this experiential uniformity, the question arises of how such a general social phenomenon has been localized by discursive means. To test how this macro-event has been translated into local micro-events and to highlight similarities and differences, we have performed a comparative analysis of 29 countries across four continents, grounded in Koller's $(2012,2014)$ notions of in-, out-, and affiliated groups.

\section{Theory and method}

We understand political discourse as collective decision making (Klein, 2000, 2019; Fairclough and Fairclough, 2012) in which a course of political action needs to be legitimized on the basis of common values and of a shared understanding of the situation and the issue in question (Chilton, 2004). Importantly, it is not only the course of action that is socially and discursively legitimized, but also the question of who can act on behalf of whom and how socio-cognitive representations of political collective entities such as states, nations, governments, and institutions are discursively constructed and contested.

Discourses of COVID-19 are evidently crisis discourses, as they concern a perceived threat to life (Gjerde, 2021, p. 7) which, as with other pandemics, brings about emotional urgency and 'elicits [an] immediate and widespread response' (Rosenberg, 1989, p. 1). Within risk and crisis management communication, the crisis is defined as 'the perception of an event that threatens important expectancies of stakeholders' (Coombs, 2010, p. 99). This perceived disruption or violation of a specific order is then discursively constructed as a crisis (Hay, 1996). There is a long tradition of discourse research on crisis discourse, with work in discourse linguistics (Wengeler and Ziem, 2014), as well as in sociologically-oriented discourse analysis (Jessop, 2013) over the last decade focusing mainly on economic crises. In critical event studies, normally linked to the field of event management, Montessori (2016, p. 132) extends the notion of critical events to global political events, which are driven by media logic. In critical realist fashion, she understands these events as existing outside of discourse but nevertheless gaining significance through discursive processes. Similarly to Jessop (2013), she warns that it would be a mistake to see 'events as isolated moments' (Montessori, 2016, p. 144).
Zamponi and Bosi's (2016) analysis of newspaper representations of the global financial crisis highlights its country-specific manifestation, which reinforces Blommaert's (2010) observation that globalization does not lead to materially or linguistically uniform structures (see also Blommaert, 2020). Every global crisis, according to De Rycker and Don (2013, p. 19) is, therefore 'the outcome of local events and trends in specific places and [...] is shaped by particular histories. To sum up, the available literature suggests that crises are discursively constructed events, but this construction depends on socio-cultural and political factors at a local level.

One of the salient values addressed and highlighted in the COVID-19 crisis discourse is solidarity. Generally, solidarity is conceived as an element that is essential for social structuring, both on the interpersonal and intergroup levels. If, in line with Durkheim $(1984$, p. 331), we consider solidarity to be the 'totality of bonds that bind us to one another and to society, which shape the mass of individuals into a cohesive aggregate', then solidarity appears to be the basic feature of human interaction and has to be discursively conceptualized accordingly. However, solidarity is neither a homogeneous nor a stable concept. It displays numerous varieties in regards to both form and structure and can oscillate across different periods, such as times of quiescence and times of crisis (Crow, 2010, p. 59). In addition, the linguistic realizations of these varieties differ considerably across texts and languages.

Starting with the discursive history of the concept, Bayertz (1999) lists four interrelated dimensions of solidarity: human, including family and blood ties; political, covering group active interest ties; social, relating to feelings, history and cultural ties; and civic, including economic or financial solidarity within a welfare state. Norms of solidarity are mainly of a horizontal nature (interpersonal and intergroup), but also involve a vertical dimension (rulers-ruled). Some authors, therefore, distinguish between institutionalized and informal solidarity (Kourachanis et al., 2019, p. 680), the former referring to the state as the main carrier of common interests and actions, with the latter pointing to non-state-actors, such as NGO's or family structures. Noting the increasing individualization of postmodern societies, some scholars speak about 'solidaristic individualism' (Rothstein, 2017, p. 313) and 'hidden solidarities' (Spencer and Pahl, 2006), referring to the rising relevance of informal social networks such as friendships. Solidarity implies that people bond on the basis of the same or at least convergent interests and/or emotions.

In view of solidarity as a complex phenomenon, we adopt the proposal by Wallaschek (2020) to analyze solidarity as a meaning-making process focusing on both its content enfolding in discourse and the actors who are included in or excluded from this content. Solidarity is a feature of group building, both in the sense of community and society. Since individuals are members of more than one group, various types of solidarity interlock, as Bayertz (1999, p. 28) emphasizes. Nation, as an 'imagined community' (Anderson 1983), is one of these possible social groups. In this vein, Malešević (2013, p. 14, 2020, p. 1) claims that solidarity is attached to nationhood, as 'for an overwhelming majority of inhabitants of this planet, nationhood is understood to be the principal form of human solidarity'. In contrast, some scholars have argued that global solidarity is generally being questioned by the rise and strengthening of nationalism during the COVID-19 pandemic, as the nation-oriented reactions to the pandemic were a prominent recurrence during the initial crisis management phase. This can be explained by the fact that responsibility for public health lies with sovereign (nation) states and that 'the nation-state - the institution-is the gravitational constant that determines politics' (Ozkirimli, 2020). This reflects 
the power of (nation-)states which are, according to Malešević (2020), one of the main agents responsible for the unfolding of the organizational power of nationalism.

As with solidarity, nationalism conceptually lacks both homogeneity and clarity. Traditionally, scholars have distinguished between civic nationalism, linked to shared political rights, and ethnic nationalism, tied to distinct cultural markers such as language, religion, or ancestry (Smith, 1998). There is, furthermore, a distinction between virulent, aggressive, or exclusionary nationalism (Bieber, 2020b, p. 15) and banal (Billig, 1995) or latent (Bieber, 2020a, p. 15) forms of nationalism. Importantly, these differentiations are not to be understood in absolute terms since there is often a gradual transition and overlaps between the forms. Therefore Bieber (2018, p. 521; 2020 b, p. 14) suggests that nationalism is better understood against the background of the interplay between levels and grades of inclusion and exclusion, which are the two main principles in constituting any group (van Dijk, 1998, p. 72). Within the discourse of COVID-19, a crisis has not only provoked the need to mobilize the 'image of communion' (Anderson, 1983) between all members who do not know each other but has initiated the processes of discursive (re-)identification and (re)building of ingroups and out-groups.

Furthermore, an analysis of the discursive construction of solidarity must also be attentive to the ways in which the coronavirus impacts nationalist constructions and performances in political discourse. More than any event in recent history, the COVID-19 crisis successfully highlights the complicated relationship between nationalism and transnationalism and has increased the relevance of Bieber's (2020b, p. 187) argument that ' $\mathrm{w}$ ] hile nationalism appears to be the antithesis to globalization, it is also closely intertwined with it'. Whilst efforts to curtail the pandemic are more distinct and determined at the level of the nation-state, as 'it is states that have armed forces; control police; mint currency; permit or refuse entrance to their lands; states that recognize citizens' rights and impose their duties' (Archibugi, 2003 , p. 1), the pandemic itself engenders a cosmopolitan/cosmopolitical response from transnational institutions such as the World Health Organization (WHO) and through the circulation of newly-created shared discourses, protocols, and practices associated with the crisis (e.g., shelter in place, social and physical distancing; see Blommaert, 2020). The COVID-19 pandemic is an instance of what Archibugi (2003, p. 3) identifies as one of the 'elements of which spontaneously escapes national government control'. Indeed, it was in response to the WHO's declaration of a COVID-19 pandemic that the speeches analyzed in this study were delivered. In that sense, there appear to be two interrelated and, in some contexts, competing 'imagined communities' (Anderson, 1983): the national imaginaire-where the power of the nation-state is directly imposed and felt-and the transnational imaginaire reinforced by the coronavirus' spread and circulation.

The complex links between nationalism and transnationalism are reinforced by the geopolitical context within which the outbreak of the pandemic has occurred; that is, in a historical moment characterized by a rise in populist nationalism, alongside an emphasis on 'trade protectionism' and 'migration controls' (see Bieber, 2020b, p. 190 and Woods et al., 2020, pp. 808-809).

We regard both solidarity and nationalism to be discursive strategies of social grouping based upon inclusion and exclusion. These strategies can be used both complementarily and contrastively. Two heuristics guide our analysis: The social construction of political identities in terms of nationalism and solidarity in the crisis communication reacting to the COVID-19 pandemic, and the argumentative legitimation of political actions.
Contextualization plays a crucial role in analyzing political text and talk. In this respect, we are guided by the three-dimensional model suggested by Norman Fairclough (2010, pp. 131-134) that distinguishes between the macro level (the social and institutional context), meso level (participants, their roles and practices, genre), and micro level of a text.

At the macro level, we have encountered a problem concerning comparative analyses of political cultures and systems. Due to the limited space of this article, it is not viable to incorporate a systematic comparative analysis of political orientations and systems and to critically appraise the existing democracy indexes and their ideological shortcomings (for more details see Munck, 2009; Skaaning, 2018).

Regarding the meso level, we understand political speeches to be a broad, overarching, and heterogeneous genre of political discourse, inclusive of text types such as a press conference speech, or an address to the nation. This genre involves presenting 'evidence, authority, and truth, a process that we shall refer to in broad terms, in the context of political discourse as "legitimation"' (Chilton, 2004, p. 23). In the context of COVID19 , the legitimation of proposed measures, policies, and representations are closely linked to coercion, exercised by political actors by setting policy, determining topics of discussion, making assumptions about the future development of the pandemic, and controlling representation (Chilton, 2004). This is especially relevant in leaders' COVID-19 speeches, which are mostly consent-oriented, attempting to garner approval from the population, and thus associated with the formation of positive public attitudes towards proposed measures and crisis management process (see Reisigl, 2008, pp. 251-252).

The research on social categorization as one of the basic processes of social cognition and the linguistic means by which they are expressed is elaborated upon within the socio-cognitive approach to discourse analysis (Koller, 2012, 2014; van Dijk, 2012). The distinctive feature of the socio-cognitive outlook lies in inferring the Socio-Cognitive Representations (SCR) from texts produced in a particular social context. SCRs are conceptual structures that Augoustinos et al. (2006, p. 42) describe as 'organized, coherent, and socially shared sets of knowledge about an object or domain'. Thus, collective identities are seen as sociocognitive representations 'comprising beliefs and knowledge, norms and values, attitudes, and expectations, as well as emotions' (Koller, 2012, p. 20).

This knowledge can emanate from different sources, such as media, the norms, and values of the community on which expectations are built and evaluations of groups are performed. Such categorizations lead to the construction of group identities in discourse (Koller, 2019, p. 71) and the discourse space occupied by them (Chilton, 2014, 2017; Cap, 2017). SCRs are dynamic and flexible, as they manifest contradictory elements and thus are not necessarily internally consistent, which may lead to their change over time (Augoustinos et al., 2006, p. 99).

The basis for the distinction between individual groups, mainly in-groups and out-groups, is a construction of difference, also known as bounding: construction of limits and boundaries (Koller, 2019, p. 71). The in-group construction is based upon self-categorization, being expressed by self-attribution, assignment of action, motivation, and shared values. Besides in-groups and out-groups, Koller introduces the affiliated group as different from the in-group; however, it is 'sympathetic' or at least neutral towards the in-group and it shares, at least partially, some of its goals, norms, and values. 'Members of the in-group and affiliated group are likely to have a positive attitude towards each other. The phenomenon of affiliated groups can be found in a range of social, including institutional contexts, including coalition partners in politics or allied nations' (Koller, 2019, p. 72, emphasis by 
authors). From the perspective of discourse space theory (Chilton, $2004,2014,2017)$ and its application within the proximization theory (Cap, 2013, 2017), the affiliated group is located within the in-group discourse space, sharing space and time with the ingroup, but differing on the axiological level, which is determined by values, beliefs, and ideology (Wieczorek, 2013, p. 215).

Based on the discussion above, we aim to answer the following overarching research question:

Does the pandemic crisis discourse challenge or enhance the concept and practice of solidarity, and to what extent is it associated with nationalist discourses?

RQ 1: How is horizontal and vertical solidarity linked to the discursive construction of in-groups, out-groups, and affiliated groups?

RQ 2: Which of the two interrelated and, in some contexts, competing 'imagined communities' (the national imaginaire and the transnational imaginaire of the pandemic) dominates the construction of solidarity in the data, and why?

\section{The corpus}

COVID $-19^{1}$ is the latest manifestation of a collective human event, among which are AIDS, Ebola, and Zika. However, the relative speed and ease with which the virus spreads have caused a staggering impact, the range, and severity of which has never been seen before. Our research performed a comparative analysis of the first statements by leading politicians in 29 countries in 4 continents from the Global North, South, and East (see Table 1). In addition to global and local perspectives, the texts in the corpus capture initial frames, arguments, and topoi which have been iterated over the course of the crisis. In addition, we aim to test the level of interdiscursivity by comparing reactions in a broad variety of countries. We have not privileged a particular region; however, we recognize the dominance of texts from Europe and North America. The composition of researchers meant that texts from Europe figure prominently (17 of 29 texts), in comparison to texts from Africa (2), the Americas (4), and Asia (6). Although the corpus was created via a convenience sampling method, it still represents a broad sample in terms of political cultures and will hopefully provide a context for future analyses of COVID-19 discourses, particularly relating to countries not here represented.

We consider 'leading politicians' to be the president or prime minister of a given nation. Of course, different political systems emphasize different roles. Presidential systems (e.g., Argentina, United States) confer substantial power to presidents, whilst semi-presidential and parliamentary systems (e.g., Malaysia, Spain) confer power to the prime minister. In considering diverse countries, we selected presidents and prime ministers because their positions are broadly similar, in that they lead the executive branch of government. The president or prime minister is a metonymic spokesperson, being the head of government and speaking on its behalf. Although we are not here distinguishing between the speaker as an animator, author, and principal (Goffman, 1981, pp. 131-40), we are aware of the complex production format of political leaders' speeches (Kranert, 2019, pp. 72-80). We have therefore simplified our analysis, in order to focus on social representations in the text, thus treating the speaker as a unified category. The president or prime minister is the highest-ranking member of the government and is an empowered representative. Their first statements are granted symbolic power (Bourdieu, 1992) as they have a broad media reach and frame the discourse that follows.

The 'first statements' explain the state of the COVID-19 pandemic in its initial stage in a particular country. These statements take the form of speeches or press conferences, delivered on national television. While the two are different genres in terms of structure, their purposes and audience are shared. These statements are an official political declaration on the COVID-19 pandemic from the government to the population (citizens or non-citizens) in the territory. Moreover, these first statements were delivered shortly after the WHO's official declaration of a pandemic on 11 March 2020. 23 leaders delivered their statements within a week, with 6 leaders doing so within two weeks. These first statements are emblematic, indicating the very start of a society-wide, government-led approach to handling COVID-19.

The choice of first statements by leading politicians necessitated creating a comparable corpus of texts for analysis. These texts were readily available on the government websites of the respective countries. As such, official transcripts were provided. Whilst these transcripts contain details of spoken language, other multimodal features were noticeably absent, such as facial expression, gesture, and body language. While multimodal features are crucial (Ledin and Machin, 2018), the focus of our analysis is at the textual micro level of the first statements. We created a corpus of 29 separate texts, one for every country in Table 1. Besides English (which accounts for four speeches), the speeches were given in 25 different languages. The examples used in the analysis were translated into English, which is the metalanguage employed by this paper's researchers.

\section{Findings}

Out-group construction. The selected speeches problematize the pandemic and the coronavirus which is identified as a threat (see also Gjerde, 2021) needed to be addressed. The widespread metaphorical renderings of the virus, particularly through personifications, make it appear within the social representation of actors as an out-group, concretely as an enemy. In the repertoire of discourses of illness, war metaphors are widely established. Sontag (1989) observed vividly how war metaphors proliferate in such discourses, and they are widespread in the discourses of COVID-19 after the pandemic was declared. Political leaders such as Trump and Macron affirm in their messages that they are at war (Craig, 2020). War metaphors are also abundant in Singapore and Malaysia (Rajandran, 2020). In our corpus, the personifications are often realized through the virus being the object of a verb construing a PANDEMIC AS WAR frame: The virus needs to be fought, defeated, destroyed either by the nation in question (UK, Italy, USA) or the people of the country (Indonesia, Singapore), but in the metaphorical war frame, it is rarely a global fight (only in the Spanish speech):

(1) Ypač dèkojame medikams, pareigūnams, kariams, savanoriams, kurie stovi pirmose kovos su virusu fronto linijose. (Lithuania, Skvernelis, 12 March 2020)

We are especially grateful to doctors, officers, civil servants, the army, volunteers who stand at the frontline of the fight against the virus.

(2) [...] combate frente al virus que libran todos los países del mundo y, en particular, nuestro continente, Europa. (Spain, Sánchez, 13 March 2020)

[...] the fight against the virus led by all countries in the world and, especially, our continent, Europe.

(3) Dans cette lutte que nous menons contre la propagation du COVID-19. (Côte d'Ivoire, Ouattara 23 March 2020)

In this fight that we lead against the spread of COVID-19.

Other ways of signaling the enemy status of the virus in our corpus are the construction of the PANDEMIC AS MOVEMENT and the virus as entering the national space. This is based on the general concept of a virus spreading through space, a metonymic construction of space for people. 


\section{Table 1 Countries and languages studied.}

\begin{tabular}{|c|c|c|c|c|}
\hline \multicolumn{2}{|l|}{ EUROPE: 17} & \multirow{2}{*}{$\begin{array}{l}\text { AMERICAS: } \mathbf{6} \\
N O R T H\end{array}$} & \multirow{2}{*}{$\frac{\text { ASIA: } 4}{\text { Brunei }(\text { Mala }}$} & \multirow{2}{*}{$\frac{\text { AFRICA: } \mathbf{2}}{\text { Ghana (English) }}$} \\
\hline Germany (German) & Croatia (Croatian) & & & \\
\hline Press conference Chancellor Merkel 11 & Speech addressed to the & USA (English) & Speech to the nation & Speech to the nation \\
\hline March 2020 & nation President Milanović. & Address to the Nation & Prime Minister cum Sultan & President Nana Addo \\
\hline & 18 March 2020 & President Donald Trump & (King) Hassanal Bolkiah. 21 & Dankwa Akufo-Addo. \\
\hline & & & March 2020 & \\
\hline \multirow{5}{*}{$\begin{array}{l}\text { Austria (German) } \\
\text { Press conference Chancellor Kurz } \\
13 \text { March } 2020\end{array}$} & \multirow{5}{*}{$\begin{array}{l}\text { Bosnia and Herzegovina } \\
\text { (Bosnian) } \\
\text { Press release. } \\
\text { Presidency Chairman } \\
\text { Džaferović } \\
12 \text { March } 2020\end{array}$} & Mexico (Spanish) & Indonesia (Malay) & Côte d'Ivoire (French) \\
\hline & & Press conference & Speech addressed to the & Speech addressed to the \\
\hline & & President Andrés Manuel & nation President & nation President \\
\hline & & López Obrador & Joko Widodo & Alassane Ouattara \\
\hline & & 24 March 2020 & 15 March 2020 & 23 March 2020 \\
\hline \multirow{6}{*}{$\begin{array}{l}\text { Switzerland (German, Italian, French, } \\
\text { Romansh) } \\
\text { Press conference Group of Bundesräte } \\
\text { (Simonetta Sommaruga, Alain Berset, } \\
\text { Karin Keller-Sutter, Viola Amherd) } \\
16 \text { March } 2020\end{array}$} & Montenegro (Montenegrin) & Cuba (Spanish) & \multirow{6}{*}{$\begin{array}{l}\text { Malaysia (Malay) } \\
\text { Speech addressed to the } \\
\text { nation. Prime Minister } \\
\text { Muhyiddin Yassin } 13 \\
\text { March } 2020\end{array}$} & \\
\hline & Speech addressed to the & Televised show in national & & \\
\hline & nation President Djukanović. & TV programme, Mesa & & \\
\hline & 18 March 2020 & Redonda & & \\
\hline & & President Miguel Díaz- & & \\
\hline & & 20 March & & \\
\hline United Kingdom (English) & Serbia (Serbian) & SOUTH & \multirow{30}{*}{$\begin{array}{l}\text { Singapore (English, Malay, } \\
\text { Mandarin) } \\
\text { Speech addressed to the } \\
\text { nation Prime Minister Lee } \\
\text { Hsien Loong } \\
12 \text { March } 2020\end{array}$} & \\
\hline Press conference Prime Minister Boris & Speech on TV President Vučić. & Brazil (Portuguese) & & \\
\hline \multirow{3}{*}{$\begin{array}{l}\text { Johnson }+2 \text { sclence experts } \\
12 \text { March } 2020\end{array}$} & 15 March 2020 & Speech to the nation. & & \\
\hline & & President Jair Bolsonaro. & & \\
\hline & & 20 March 2020 & & \\
\hline Spain (Spanish) & North Macedonia (Macedonian) & Argentina (Spanish) & & \\
\hline Address to the nation. Prime Minister & Speech addressed to the & Speech to the nation & & \\
\hline President & nation President Pendarovski. & President Alberto & & \\
\hline Pedro Sánchez & 18 March 2020 & Fernández & & \\
\hline 13 March 2020 & & 13 March 2020 & & \\
\hline Netherlands (Dutch) & Czech Republic (Czech) & Chile (Spanish) & & \\
\hline Press conference Prime Minister Mark & Broadcasted speech-address & Press Conference. & & \\
\hline Rutte, Health minister Bruno Bruins, & to the nation. & President Sebastián Piñera & & \\
\hline 1 science expert & Prime Minister Andrej Babiš & Echenique & & \\
\hline 12 March 2020 & 23 March 2020 & 13 March 2020 & & \\
\hline Belgium (Dutch, French) & Slovakia (Slovak) & & & \\
\hline Speech in Parliament & Broadcasted address to the & & & \\
\hline Prime Minister Sophie Wilmès & nation. & & & \\
\hline 19 March 2020 & President Zuzana Čaputová & & & \\
\hline & 19 March 2020 & & & \\
\hline Italy (Italian) & Russia (Russian) & & & \\
\hline Speech addressed to the nation & Broadcasted speech-address & & & \\
\hline Prime Minister Giuseppe Conte 11 & to the nation. & & & \\
\hline March 2020 & President Vladimir Putin & & & \\
\hline & 25 March 2020 & & & \\
\hline \multicolumn{4}{|l|}{ Lithuania (Lithuanian) } & \\
\hline \multirow{2}{*}{\multicolumn{4}{|c|}{$\begin{array}{l}\text { Speech broadcast by the national } \\
\text { broadcaster }\end{array}$}} & \\
\hline & & & & \\
\hline \multirow{2}{*}{\multicolumn{2}{|c|}{$\begin{array}{l}\text { Prime Minister Saulius Skvernelis } 12 \\
\text { March } 2020\end{array}$}} & & & \\
\hline & & & & \\
\hline
\end{tabular}

(4) Das erste war das Thema der Eindämmung der Gefahr, die von dem Coronavirus ausgeht. Das Virus ist in Europa angelangt. Es ist da. Das müssen wir verstehen. (Germany, Merkel, 11 March 2020)

The first topic was the containment of the danger originating from the coronavirus. The virus has arrived in Europe. It is here. We need to understand that.

(5) ... ито Россия - просто даже в силу своего географического положения - не может отгородиться от угрозы. Рядом с нашими границами находятся государства, уже серьёзно пораженные эпидемией, и полностью заблокировать её проникновение в нашу страну объективно невозможно. (Russia, Putin, 25 March 2020)

...that Russia-simply because of its geographic locationcannot fence off the threat. Near our borders, there are states that are already seriously affected by the epidemic, and it is objectively impossible to completely block its penetration into our country.

Some differences in the construction PANDEMIC AS MOVEMENT indicate the varying temporal developments of the pandemic: when it had arrived in Germany and was recognized as such, Ghana had not reported any cases but was preparing for a possible entry of the virus within its borders. In this case, the warning is reinforced by the reference to a sizable Ghanaian population in Europe, which is affected by a rise in the number of COVID infections there. The reference to the virus' presence there, as well as in neighboring African countries, stresses the closeness of the pandemic to Ghana despite the absence of local exigency.

(6) Fellow Ghanaians, as you may have heard in the news, Burkina Faso, our Northern neighbor has confirmed their first two cases of Coronavirus infections. Togo to our East has one confirmed case. Côte d'Ivoire to our West also has one confirmed case. (Ghana, Akufo-Addo, 11 March 2020)

The construction of the virus moving closer to the deictic center of the in-group with accelerating speed increases the urgency of the threat and the necessity to take action.

(7) Meine Damen und Herren warum ist das so wichtig? Weil wir die Verbreitung des Virus verlangsamen müssen, damit es in den Spitälern weiterhin genug Platz hat. (Switzerland, Sommaruga, 16 March 2020) 
Ladies and Gentleman, why it is so important are because we have to stop the spread of the virus so we will continue to have enough beds in hospitals.

The only text in the corpus that does not construe the virus as an enemy is negationist Bolsonaro's speech. Bolsonaro describes the virus as rain ('It will wet $70 \%$ of you') and compares it to the flu which allows him to argue that economic problems take precedence over the health effects, coining the slogan 'Brazil can't stop'.

Overall, the virus is mostly either rendered as an enemy combatant, or depicted as having entered the geographical space, or rather discursive space, of the nation-state. In his analysis of the Norwegian discourse on COVID-19, Gjerde (2021, p. 9) suggests that the construal of the virus as a war mongering outgroup actor creates 'a common human identity through the exclusion of the non-human actor' and therefore provides motivation for increased community solidarity. However, the dominant metaphorical frames in the corpus (PANDEMIC AS WAR and PANDEMIC AS MOVEMENT) both assume the nation-state as a frame of reference and source of solidarity. This is not surprising, as the macro and the meso level of the speeches are truly national. They are delivered by the representatives of the national executive and present the protective measures to mitigate the national impact of the virus. The focus of the community solidarity on the nation-state is counterbalanced in most speeches by the recognition that the virus is a global threat and by the emphasis on the necessity of regional collaboration, construing neighbors, partners, and global institutions as affiliated groups. The construction of specific countries or regions as an out-group is an exception rather than a rule. Indeed, China is sometimes acknowledged as the geographical origin of COVID-19, but only US President Trump is clearly communicating it as an out-group. In his expression, 'foreign virus' China is framed as dangerous and threatening human lives, and Trump demands credit for 'early action on China' via a travel ban. Blame for the COVID-19 crisis is then extended to the European Union, which Trump criticizes for its failure to restrict travel from China and other affected countries. Similarly, the EU as an institution is constructed as an out-group in the Serbian presidential speech, where the EU's ideal of solidarity is deconstructed as a fairy tale. The Serbian president extends solidarity, however, only to some European countries, specifically Italy and Spain.

Cuba implicitly evokes the US as a historical enemy, to construe the country as a nation at war. The historical experience in resisting 'traditional adversaries' is used to construe Cubans in crisis situations and invoking the values of humanism as successful principles that will guide Cuba safely through the pandemic. This implicit invocation of an out-group is therefore a more historical topos to illustrate the historical origins of the values of Cuba.

The absence of specific national out-groups in a great part of our corpus points to the speakers' rhetorical aim of uniting rather than dividing the population. This, however, does not necessarily indicate unity on a deeper level. As Huber (2020, p. 400) has observed for the rhetoric of the cholera epidemic and the deeper discourses of dealing with it: 'Despite the overarching rhetoric of universality and brotherhood, the lengthy debates of the early international sanitary conferences illustrate the difficulties in reaching agreement'. The controversial topics of openness and closure, which were also found in the debates of quarantines and isolations of the cholera pandemic, were yet to enter the COVID19 discourse.

The results show that exclusionary reasoning is realized explicitly or implicitly by means of discursive othering. Concretely, certain irresponsible or non-compliant members of the in-group are stringently ruled out. This is a well-known mechanism that can be found in the history of pandemics (for the cholera pandemic, see Huber, 2020). Irresponsible members are viewed as diverging from solidarity norms, convergent societal interests, shared emotions and values such as discipline, reasoning, etc. This kind of discursive construction is related to the conception of solidarity as an element of particular social problems or conflicts. As Crow (2010, p. 58) argues, they occur when it [solidarity] takes the form of coercion on members to behave in ways that they would not have freely chosen.' In essence, the conflict between individual and communal interests develops.

In most of our cases (23/29 countries), quarantine violators are not mentioned directly, partly because this was to be reserved for later stages. For example, in Germany, there had yet been no quarantine announced. Mostly, the members of the society whose behavior diverges from what is expected during the pandemic crisis are viewed as undisciplined and irresponsible. Three countries (Czech Republic, Serbia, and Argentina) involve explicit mentioning of those who break the set rules. The Czech Prime Minister, for example, refers to people who do not observe the imposed measures as 'the blokes who are supposed to be in quarantine':

(8) Frajírci, co mají být v karanténě a klidně si dají společně pivo u dveři hospod, to fakt nejsou žádní hrdinové. Spís zbabělci, kteři si neumí nic odř́ct. Ani na pár dnů. I když dobře vědí, že touhle svojí frajeřinou můžou nakazit své dět $i$, ženu nebo staré rodiče nebo prarodiče, které koronavirus ohrožuje nejvíc. (Czech Republic, Babiš, 23 March 2020)

The blokes who are supposed to be in quarantine are drinking beer at the pub's door together without any remorse. These are no heroes. These are cowards who are not able to refrain from drinking. Not even for a couple of days. Even though they know that this showing off may be a way of becoming infected and then infecting their children, families, elderly parents or grandparents who are threatened by the coronavirus the most.

Both the Serbian President and the Argentinian President threaten lockdown with potential legal consequences:

(9) Policija će da sprovodi nadzor nad izolacijom. Onaj ko bude prekršio izolaciju, naredbu o izolaciji, dobiće do tri godine zatvora. Odmah. (Serbia,Vučić, 15 March 2020)

The police will monitor the isolation. The one who violates the isolation, the ordered isolation, will get up to three years in prison. Immediately.

Lastly, there are three countries (Spain, Lithuania and Côte d'Ivoire) where there are no direct mentions of quarantine violators, but rather implicit references to what is considered to be right under the given circumstances (such as 'disciplined', 'responsible' and therefore 'brave' individuals, as in the case of Spain). This can be interpreted as governmental insistence on solidarity-related values which are needed to implement governmental decisions. Implicitly, those individuals who are not responsible and disciplined break the societal need for (and value of) solidarity in the given circumstances and are stigmatized as out-groups. Similarly, the Lithuanian PM states that those who do not show solidarity and do not do what is required are acting wrongly against disciplined and responsible members of the society. Importantly, some individuals are constructed as outgroup members by holding onto negative values such as selfishness and arrogance:

(10) Hay que cerrar el egoísmo en la reacción a las amenazas que comporta el momento. (Cuba, Díaz-Canel, 20 March 2020) 
We must avoid egotism in our reaction to the threats that the virus brings about [other countries being egotistic by not accommodating a British ship with COVID-19 passengers; the authors].

It is common in these speeches to evoke blame for the adversaries who are easily recognizable by members of the ingroup. More often than not, these adversaries are usually internal to the country. In Brazil, Mexico, Croatia, Montenegro, and Serbia, they are part of the opposition and their goal is to divide and scare citizens by spreading fake news and disinformation. Brazil constitutes the most extreme case, where governors and mayors are said to be damaging the country by closing tradethey are outcast for acting against Bolsonaro's strategy of COVID-19 denial. We can bring a clear example of the negativism expressed by Bolsonaro in one of his sentences that was widely publicized in the press, by the concept of "little flu":

(11) ...caso fosse contaminado pelo vírus, [eu] não precisaria me preocupar, nada sentiria ou seria, quando muito, acometido de uma gripezinha ou resfriadinho... (Brazil, Bolsonaro, 24 March 2020)

...if infected by the virus, [I] wouldn't have to worry, I wouldn't feel anything or would be, at most, like affected by a 'little flu'.

Less extreme, but still stifling opposition early on, we find the Serbian President claiming that the 'bravest' and 'great' people 'who saved us from the hardest times' (i.e., doctors) have been attacked, which in the context of other speeches appears to be a strategy: critical questioning framed as an 'attack'.

Not only did we find cases of othering opposition to the government strategy, but we also found some ambivalent constructions of both businesses and the media in first reactions to the crisis, i.e., cases where business or the media were construed as an out-groups in one country, but in-groups in another. For example, in some countries from the Global South, such as Ghana and Cuba, businesses are not framed as an outgroup, but as a source of national defense and an opportunity for strengthening self-reliance. Therefore, there is a clear government-business alliance that will shield against the virus, but also against foreign dependency. In Brunei, however, businesses were in danger of becoming an out-group and warned not to raise prices to make a profit.

The media was also treated with ambivalence in many countries. They are clearly vilified only in Mexico (where attempts were made to frighten people with 'fake news') and in Cuba (since the foreign media is seen as traditionally attacking and 'distorting' the image of the country). In Cuba, 'big media' is accused of either keeping quiet on Cuba's achievements or offending and attacking the Cuban government/people. In the case of Ghana, the media are framed as an out-group, helping to disseminate the wrong information, which refers to 'false' information from unverified or dubious sources. The discursive construction of 'proper' versus 'wrong' concerns not just journalistic standards, but also political goals. In Ghana, the President asked media outlets to disseminate information that has been previously proved and authorized by health authorities. At the same time, the media can be constructed as an affiliated group inasmuch as it disseminates 'proper' (Austria, Ghana) verified information through trustworthy channels (such as the mainstream media).

In-group construction. In the analyzed speeches, in-groups are construed as crucial for overcoming the crisis. The underlying value for such construction is solidarity between its members.
Solidarity enables members of in-groups to coalesce around endeavors to manage COVID-19. By this narrative, solidarity is necessary as everyone in the country must work together in order to successfully manage the COVID-19 crisis: Political leaders cannot do it by themselves and need contribution or compliance from their citizens. The joint population-government contribution reveals the construal of a vertical and institutionalized aspect of solidarity (Kourachanis et al., 2019). Citizens are constructed as in-group members, as the Presidents and Prime Ministers often address their audience as a unified nation, for which they portray a common vision in their statements. Such a portrayal should motivate people who are not directly known to one another to feel united, in what has been defined as an imagined community' (Anderson, 1983), whose members will hold in their minds mental images of their solidarity. This stimulates the horizontal construction of collective responsibilities, actions, and emotions.

At the micro level, the in-groups are discursively constructed by means of personal and possessive pronouns, noun phrases, and metonymic references. These speeches, in fact, often address the audience as a nation, and the nation in many countries is presented as a team (such as in Austria, Spain, the Netherlands, Belgium, Italy, the Czechia, the US, Mexico, Cuba, Ghana, and Côte d'Ivoire):

(12) Tardaremos semanas, pero pararemos unidos al virus. (Spain, Spain, Sánchez 13 March 2020)

It will take us weeks, but we will stop the virus together.

(13) Österreich ein Team, ein Team, in dem jeder seinen Beitrag zu leisten hat, gerade in einer herausfordernden situation. (Austria, Kurz, 13 March 2020)

We as Austria are a team, a team in which everybody has to contribute in face of this difficult situation.

Similar examples can be found in the Netherlands and Ghana. The nation-as-team metaphor unifies the population fighting COVID-19 and solidifies the in-group because it implies their equal and joint contribution in managing the pandemic. Presenting one's country as a team seems to meet the national imaginaire (Anderson, 1983), as teams are associated with nations. This can be seen in the values (such as responsibility, generosity, and particularly solidarity) associated with the ingroups, which are often named directly and in the association.

(14) Da sind unsere Solidarität, unsere Vernunft und unser Herz füreinander schon auf eine Probe gestellt, von der ich mir wünsche, dass wir sie auch bestehen können. (Germany, Merkel, 11 March 2020)

Here, our solidarity, our reason and our heart is tested, and I hope we will pass that test.

(15) Het verantwoordelijkheidsgevoel, de solidariteit, de moed, maar ook het vertrouwen in ons vermogen om weer op te staan, om sterker uit deze beproeving te komen, moeten ons meer dan ooit drijven. (Belgium, Wilmès 19 March 2020)

The sense of responsibility, the solidarity, the courage, but also the confidence in our ability to get up again, to emerge stronger from this ordeal, must drive us more than ever.

(16) V̌̌etci sme spojení v solidarite, všetci sme si v hrozbe ochoriet' rovní a všetci sa navzájom potrebujeme. (Slovakia, Čaputová, 19 March 2020)

We are all united in solidarity, we are all equally facing the threat of getting ill and we need each other.

(17) Апелирам до сите граѓани на нашата заедничка и единствена татковина, да бидеме смирени, да бидеме одговорни и да бидеме солидарни еден кон друг. (North Macedonia, Pendarovski, 18 March 2020) 
I appeal to all citizens of our common and unique homeland, to be calm, to be responsible, and show solidarity with each other.

In addition to inclusive first-person plural pronouns, expressions such as 'people' and 'citizens' are frequently and primarily used in an inclusive sense. Local variations of these expressions such as 'compatriots' in Chile and Spain and 'friends' in Russia can be seen in the corpus. The speech from Cote d'Ivoire addresses the population with the demonymic form 'Ivorians'. Demonyms are also found in the speeches of Austria, Italy, and the United States, but are criticized in public discourse as potentially less inclusive (Bieber, 2020a, p. 8).

The speakers name several members of the in-groups in their statements, including the government and the population with some units being specified, namely families, the elderly or younger citizens, and specific professions. In doing so, their key role in the endeavor against the virus is underlined. Indeed, the government manages the virus at the national level, with the population being expected to trust it and adhere to or comply with governmental directives.

The speakers as the representatives of the governments and their institutions construct the discourse space, with its deictic center and thus spatial and temporal dimension, and the pertinent axiologies represented by common goals and values of the in-group. The government as part of the in-group is common to the whole corpus, it is referred to through nouns, such as Bundesrat (Switzerland), el Estado (the State, Argentina), Kerajaan (Brunei, Malaysia), Pemerintah (Indonesia, Singapore), Gobierno (Government, Spain, Chile, Cuba). The only exception is Brazil, where Bolsonaro clearly addresses 'the people' directly. This points to and enhances the national imaginaire grounded in the fact that governments as the center of political action are based on the institution 'nation-state' (Ozkirimli, 2020).

Speakers also use 'we', a pronoun at times both inclusive and ambiguous, to conflate government and the population as one unit, presuming their unity, and permitting the government to act on behalf of citizens, assuming their support. This can be found in Austria, Germany, United Kingdom, Italy, Singapore, Brunei, Argentina, Chile, Spain, and Cuba. The use of the first-person plural represents the speaker as a central in-group member speaking on behalf of the whole group (Wortham, 1996, p. 333), an effect that is based on the double indexicality of personal pronouns (Mühlhäusler and Harré, 1990, p. 92). This effect is well documented for leaders' speeches in Western democracies (Fetzer and Bull, 2012; Kranert, 2017) but can be observed in our corpus at a global level.

These nouns and pronouns are often the subject of clauses, representing the government's management of actions and decisions. The government leads to action and activities in its country because it has a special claim to legitimacy based on electoral consent through elections and under the constitution. For example, in the speech by the Group of Bundesrat in Switzerland the exclusive 'we' is always in subject position in sentences about decisions:

(18) Wir brauchen jetzt auch die Bevölkerung die sich an diese Maßnahmen hält und zwar die ganze Bevölkerung jeder und jede einzelne von uns. (Switzerland, Sommaruga, 16 March 2020)

We now need the population that follows the rules, that means the whole population.

Some of the countries refer to federalism as a government subcategory which, for German Chancellor Merkel, 'means responsibility', whereas Belgian Prime Minister Wilmès mentions 'the great union that I have called for, with the will to work together constructively in the interests of all':
(19) Deze motie van vertrouwen maakt deel uit van de "grote unie" waartoe ik heb opgeroepen, met de wil om constructief samen te werken in het belang van iedereen. (Belgium, Wilmès, 19 March 2020)

This vote of confidence is part of the "great union" (on a federal level, CS) that I have called for, with the will to work together constructively in the interest of all.

Spanish Prime Minister Sánchez thanks regional governments, whilst the American President Trump mentions federal agencies and federal health experts, nevertheless affirming that 'we are marshaling the full power of the federal government'.

A prominent in-group encountered throughout the speeches are healthcare workers. This group is composed of doctors and nurses, who are thanked for their hard work and sacrifice. While the earlier in-groups require protection, healthcare workers provide protection because their activities help to curb COVID19. The in-group is not seen in Argentina, Chile (although there are references to scientists and international health organizations), Indonesia, Singapore, and the United States. In these first speeches, the President/Prime Minister tries to explain the virusrelated situation, as the impact of the virus has not yet completely manifested itself.

Related to the group of healthcare workers is the recurring subgroup of experts, mainly involved within the scientific and medical fields. They are fundamental to the countries' leaders accomplishing their goals of curing COVID-19 patients and preventing others from being infected. The experts are presented in different grades of specificity, which can be summarized as named professionals, institutes, institutions, and unspecified workers in the scientific or medical field. Thus, there is an overlap with the group of healthcare workers. German Chancellor Angela Merkel mentions the German Robert-Koch-Institute and expert Lothar Wieler. Similarly, the speakers from the United Kingdom, the Netherlands, Italy, and the Czech Republic refer to national experts through their speeches, and they are often physically present in the press conference. The Presidents of Ghana and Ivory Coast both mention their national Ministries of Health, institutes, and research centers.

Experts as part of the in-groups are generally mentioned from a national perspective, notwithstanding the global aspect of the pandemic. The representation of this group, therefore, enhances a concept of localized solidarity: it mainly consists of national actors. In addition, the strong national construction of the expert group is a tool for conveying the idea of the in-group having the competency and/or the resources to manage the pandemic from the healthcare point of view. Openly mentioning national experts and institutions in the scientific and medical field is a way of openly stating support and power at the same time. The only exception occurs in Chile, where President Sebastián Piñera Echenique speaks of 'international health authorities'.

Another state-related and nationally specific category that is constructed as an in-group is the army; however, it is present in fewer instances when compared to the experts and is approached differently. It is true that the military may be mentioned less because several countries had experienced military coups or dictatorships, and the mention of the military in relation to defense may evoke a return to non-democratic governance. In Lithuania, Prime Minister Skvernelis refers to the army by thanking it together with others. Here, the army is seen as cooperating with the government in the emergency, therefore sharing goals and efforts with the national 'Us'. The Group of Bundesräte in Switzerland speaks about the army for its helping role in 'social care and healthcare. In the Ivory Coast, the army is not praised or thanked, but rather called into action by President Ouattara. The construal of the group of experts and the army, 
both actors at the national level, reinforces national unity and solidarity, and thus legitimizes political action.

The family, as the basic unit of society, and its constituent members are mentioned in several countries. The family is acknowledged as an in-group in the Czech Republic, Mexico, and Slovakia. Its role in society is especially highlighted by Mexican President:

(20) La familia en México es la institución de seguridad social más importante. (Mexico, López Obrador, 24 March 2020) The family in Mexico is the most important social security institution'.

Its actions and decisions, multiplied across families, leave a tangible impact in steps towards curbing COVID-19.

Within the family, the focus is often on the elderly and the younger generation. Elderly people are referred to in the majority of speeches (18/29) of the corpus. They are constructed as vulnerable because they are particularly at risk of severe illness caused by the virus, and in need of support from other citizens. In one sense, addressing both the younger and older generations symbolizes the age span of the people in danger, meaning that the virus has the potential to infect anyone, whichever age group they may belong to. Thus, most of the countries appeal to individual responsibility in the form of staying home (e.g., Serbia, Cuba) or 'taking care of ourselves' (Spain, Czechia). In addition, there are calls for social or state support, as in Mexico, where the president asks people to take care of the elderly, and in Argentina, where the state takes on this role.

The in-groups noted in the first speeches are those that ordinary citizens would encounter in their daily lives, such as the elderly, youth, military, and healthcare workers. This evocation of personal interaction makes it easier to engender a sense of solidarity. The population is positioned as having a personal relationship with these groups and depicted as situated within them, interconnected by shared responsibility for the health of people in the in-groups. This entails sharing the common objective, namely, to curb the virus which functions as an impulse in mobilizing horizontal solidarity in face of the common danger (Kourachani et al., 2019). Horizontal and vertical solidarity are necessarily interconnected as the governments (and essentially the whole society) benefit from the promotion of horizontal solidarity, which essentially reinforces the vertical solidarity clearly needed in gaining the acceptance of governmental decisions and actions.

Affiliated group construction. Affiliated groups in our corpus create discursive alliances with the in-groups and share relatively close ties with them. Accordingly, the in-groups offer them support, express solidarity, and provide aid or receive help from them. In some cases, the affiliated groups of some countries are, however, a target of criticism in speeches of other countries (e.g., $\mathrm{EU})$. For instance, Spain and Italy are seen as countries affected by the virus towards which Serbia is showing sympathy and solidarity, even though the European Union is considered an outgroup in the same speech. In general, there are two types of affiliated groups: geographical and institutional. The first group encompasses neighboring and/or foreign countries, including both the most affected by the Covid-19 crisis and countries that were 'successful' in dealing with it.

The 'World,' as a group of countries, is mentioned to emphasize the magnitude of the coronavirus pandemic. For instance, Spain's President declares that COVID-19 is

(21) ...el combate frente al virus que libran todos los países del mundo. (Spain, Sánchez, 13 March 2020)

...the fight against the virus led by all countries in the world.
Similarly, the 'World' is also used as an affiliated group to emphasize international cooperation by Brunei's President:

(22) Tetapi kita bukanlah bersendirian, malah seluruh dunia. (Brunei, Bolkiah, 21 March 2020)

But we are not alone; in fact, the world is with us.

Quite a different perspective is taken by the Cuban President, who claims that his country is affiliated with and ready to help all those who may need it. This seems to be the central objective of Cuba's foreign relations policy, as the President himself points out:

(23) Esa misma responsabilidad, lo que nos llama es a ser solidarios, a cooperar con todos los que en el mundo necesiten apoyo y esté a nuestro alcance darlo. (Cuba, DíazCanel, 20 March 2020)

The same responsibility calls us to solidarity, to cooperate with all those in the world who need our support, as long as we're able to provide it.

Importantly, the construction of coronavirus as a global threat serves to reinforce the pre-existing alliances between countries and their foreign policies. This is often done by propping up national strengths and values. At the transnational level, the expression of solidarity is more associated with assistance and aid rather than effective cooperation. Alongside the international organizations and alliances, the data show that the construction of affiliated groups in some countries involves foreign citizens and asylum seekers, groups for whom membership in these nations is sometimes contested. This aligns well with Kloet et al. (2020) who point out that in a time in which 'geopolitical entities are ranked according to their governance and containment success', 'this celebration of biopolitical control does not fall into the classic reproduction of capital but speaks to geopolitical identification'. Unsurprisingly, the crisis situation has not only strengthened national geopolitical identifications but has also reinforced pre-existing geopolitical alliances in terms of affiliated groups or in-groups.

Neighboring countries are analyzed in terms of solidarity and mutual aid, as in the cases of Switzerland offering 'close cooperation', and German chancellor Merkel openly showing support:

(24) Natürlich wollen wir unseren europäischen Nachbarn und Partnerländern auch in der Versorgung helfen. (Germany, Merkel, 11 March 2020)

Of course, we want to help our neighbors and partners with supplies.

Cuba and Chile include other countries as affiliated groups, based upon how successfully they handled the pandemic. In the Cuban speech, 'international experience' is observed and analyzed 'systematically', serving as an example of pandemic management. In Chile and Croatia, successful experience is further specified: South Korea, together with other 'friendly countries' is given as an example of successful pandemic management in its early stages.

The institutional type of affiliated groups regards international organizations, such as the European Union, international health organizations, and global and regional economic alliances. These affiliated groups give an insight into the multidimensional discourse of solidarity and the competing representations of national and transnational communities. The countries of the European Union are referred to as 'colleagues' by German Chancellor Angela Merkel. Meanwhile, Austria and Switzerland allude to European-level decisions and exchange of ideas. In addition, other instances focus on comparing the national responses and capabilities to deal with COVID-19 with other EU members: For instance, Lithuanian Prime Minister Saulius Skvernelis said: 
(25) Pirmieji Europos Sajungoje paskelbème ekstremaliq situacija. (Lithuania, Skvernelis, 12 March 2020)

We are the first in the $\mathrm{EU}$ to announce the state of emergency.

In Croatia, EU and democratic countries, in general, are emphasized as good examples:

(26) Ohrabruje me na neki način što radimo manje-više sve isto što rade naše susjedne države, članice Europske unije, od kojih su neke najbogatije $i$ najorganiziranije države na svijetu, s najuređenijim sustavima javnog zdravstva, pa se $i$ tamo potkradaju neke stvari koje možemo nazvati greškama. (Croatia, Milanović, 18 March 2020)

I am encouraged in a way that we do more or less everything as our neighboring countries, members of the European Union, some of which are the richest and the most organized countries in the world, with the most organized public health systems, and even there things that can be called mistakes happen.

A completely different position is adopted in Serbia concerning the discourses of solidarity and nationalism. The Serbian President claimed that international and 'European solidarity does not exist', while referring to China as 'friends and brothers of our country':

(27) Ja sam danas uputio posebno pismo, jer mnogo od toga očekujemo i najveće nade polažemo u jedine, koji mogu da nam pomognu. U ovoj teškoj situaciji to je Narodna Republika Kina. (Serbia, Vučić, 15 March 2020)

I sent a special letter today because we expect a lot from that and we place the greatest hopes on the only ones who can help us. In this difficult situation, it is the People's Republic of China.

This discursive exception must be seen, first, in the context of the authoritarian ruling style by President Vučić, who decides on political friends and foes depending on what corresponds with his political goals. Second, this is in line with the Serbian national myth of being the eternal crossroad between West and East, expanding the latter in recent years to China.

The second institution which is regularly cited as an affiliated group by countries is the WHO. In Cuba and North Macedonia, it is mentioned as an international authority when stipulating and sustaining national sanitary measures. In Ghana and Côte d'Ivoire, it is thanked for its assistance and support. Brazil's President Jair Bolsonaro, on the other hand, refers to the WHO General Director to legitimize the country's strategy against the WHO recommendations, foregrounding the damage a lockdown could inflict on the poorest in society.

Via the analysis of affiliated groups, the discursive multidimensionality of solidarity and competing representations of nationalism and transnational communities can be discerned. The perception of the coronavirus as a global threat is used to reinforce pre-existing alliances between countries and their policies of international relations; each of them aims to support national strengths and values in the face of the threat. On the one hand, neighboring and foreign countries are constructed in terms of solidarity, their success in handling the pandemic, and in terms of the aid provided. On the other hand, restrictions and constraints related to them and to their inhabitants, such as the closing of borders, are announced.

\section{Conclusion}

The discursive construction of collective identities and solidarity in the crisis speeches by the premiers of 29 countries presented a complex picture, one that can best be described with Wittgenstein's idea of family resemblance:

And the upshot of these considerations is: we see a complicated network of similarities overlapping and crisscrossing: similarities in the large and in the small. I can think of no better expression to characterize these similarities than "family resemblances"; for the various resemblances between members of a family-a build, features, color of eyes, gait, temperament, and so on and so forth-overlap and criss-cross in the same way. (Wittgenstein et al., 2009, p. 36e)

These family resemblances mean that the speeches-and the discourses represented in them-share the main discursive mechanism, as they react to the same political issue in the same genre. We can therefore summarize the main global mechanisms of the first political reactions to the COVID-19 pandemic here, while the outliers from the prototypical speech point to particularities in the local political environment.

Our analysis confirms Wallaschek's (2020) idea of solidarity as a multi-layered phenomenon: In our speeches, it is first constructed vertically on the basis of national identity, as these speeches are given by national political leaders mainly speaking on behalf of a national government and addressed to their population. The genre 'speech of a head of state/government' targets national audiences and recontextualizes the practice of nation-states as established institutions reacting to global crises. The family resemblances are born at the discursive meso level: the speeches constitute an in-group based around the deictic center of the national governments. The in-groups need to collaborate to control the pandemic and minimize the risk for individual members. The first answer to our research question is that the speeches draw on a national imaginaire, which is enhanced by the genre itself, which presupposes the practice of a vertical type of solidarity (Kourachani et al., 2019). Governments and populations share a common aim in curbing the virus, and governments need to mobilize this vertical solidarity for the people to accept and apply proposed actions and decisions. Governments conceptualize this both as a joint interest (e.g., obligations, based on reason, expert opinion, and so on) and moral imperative (emotive appeals, such as to altruism). These results evidence that the practice of solidarity enables existing societal groups to be 'repurposed' in handling a new crisis: in this case, COVID-19.

Various mechanisms support the in-group construction on a national level and add layers of solidarity. Firstly, the virus as the common enemy is construed within the national imaginaire: the threat of the virus is constructed as a national threat through war metaphors and the construal of the pandemic as a dangerous movement towards the deictic center of the speech (Gjerde, 2021). Secondly, the portrayal of internal out-groups strengthens national solidarity based upon condemnation of the rulebreakers. And finally, almost all speeches refer to social groups closer to the audience and therefore refocus efforts towards horizontal solidarity: families, elderly, and children. The speeches, therefore, communicate a chance for in-groups to come together. The particular in-groups - that is, population, family, elderly, youth, military, and healthcare workers - are discursively constructed through structures that presume unity and hence consensus in actions and decisions to manage COVID-19.

Of course, the speeches also point towards a transnational level of solidarity, particularly as they mostly do not refer to national or regional out-groups. The exceptions are prototypical exclusionary nationalist leaders such as Trump accusing China, Cuba referring to its traditional enemy in the US, and Serbia doubting the solidarity of the EU. Affiliated groups in the speeches mainly reinforce pre-existing geographical alliances between countries 
but also refer to transnational institutions, such as WHO and EU. The solidarity with the affiliated groups mostly entails the provision of assistance or aid, but not the promotion of active cooperation. Indeed, alliance with the affiliated groups supports national strengths and values in dealing with this threat.

It has been argued that both the contestation of globalization and the absence of global cooperation may be linked to the decreasing superpower status of the US, as well as the growing tensions between the US and China, propelled through a kind of rhetorical war during the pandemic (Enderwick and Buckley, 2020, p. 99; Woods et al., 2020, pp. 810-812) and even before it (e.g., the US-China trade war). It is within this complex geopolitical context that one must, for instance, understand the US' disposition towards the World Health Organisation or choice of 'Wuhan or Chinese Virus' over coronavirus, with implications for the reception of people of Asian descent in the West. Thus, constructions of solidarity at the level of the nation-state-based on assumptions of a deictic center-becomes significantly entangled with a 'deictically organized geopolitical knowledge' (Chilton, 2004, 139), complicating our explorations of in-group, out-group and affiliated group constructions in the political responses to COVID-19.

\section{Data availability}

All analyzed speeches are available at the OSF repository (https:// osf.io/ug2y5/).

Received: 3 December 2020; Accepted: 10 May 2021;

Published online: 27 May 2021

\section{Note}

1 All analyzed speeches are available at OSF repository (https://osf.io/ug2y5/).

\section{References}

Anderson B (1983) Imagined communities: Reflections on the origin and spread of nationalism, Revised edition. Verso, London and New York

Archibugi D (ed.) (2003) Debating cosmopolitics. Verso, London

Augoustinos M, Walker I, Donaghue N (2006) Social cognition: an integrated introduction, 2nd edn. Sage, London

Bayertz K (1999) Four uses of solidarity. In Solidarity. Philosophical Studies in Contemporary Culture. Springer Science+Business Media, Dordrecht, pp. 3-28

Bieber F (2020a) Global Nationalism in Times of the COVID-19 Pandemic. Nationalities Paper 1-13. https://doi.org/10.1017/nps.2020.35

Bieber F (2020b) Debating nationalism: the global spread of nations. Bloomsbury Academic, London

Bieber F (2018) Is Nationalism on the Rise? Assessing Global Trends. Ethnopolitics 17:519-540. https://doi.org/10.1080/17449057.2018.1532633

Billig M (1995) Banal nationalism. Sage, London and Thousand Oaks, Calif

Blommaert J (2020) The coronavirus crisis of 2020 and globalization. In: Diggit Mag. https://www.diggitmagazine.com/column/coronavirus-globalization. Accessed 17 Sep 2020

Blommaert J (2010) The sociolinguistics of globalization. Cambridge University Press, Cambridge

Bourdieu P (1992) Language and symbolic power. Polity, Cambridge

Cap P (2017) The language of fear: communicating threat in public discourse. Palgrave Macmillan, London

Cap P (2013) Proximization: the pragmatics of symbolic distance crossing. John Benjamins, Philadelphia/Amsterdam

Chilton P (2004) Analysing political discourse: theory and practice. Routledge, London, New York

Chilton P (2014) Language, space and mind: The conceptual geometry of linguistic meaning. Cambridge University Press, Cambridge

Chilton P (2017) Toward a neuro-cognitive model of socio-political discourse, and an application to the populist discourse of Donald Trump. Lang Société 160-161:237. https://doi.org/10.3917/ls.160.0237

Coombs TW (2010) Conceptualizing Crisis Communication. In: Handbook of Risk and Crisis Communication. Routledge, New York, London, pp 99-119

Craig D (2020) Pandemic and its metaphors: Sontag revisited in the COVID-19 era. Eur J Cult Stud https://doi.org/10.1177/1367549420938403

Crow G (2010) Social Solidarities. Sociol Compass 4:52-60. https://doi.org/ $10.1111 / \mathrm{j} .1751-9020.2009 .00262 . \mathrm{x}$ de Rycker A, Don ZM (2013) Discourse in crisis, crisis in discourse. In: de Rycker A, Don ZM (eds) Discourse and crisis. John Benjamins, Amsterdam Durkheim E (1984) The division of labor in society. MacMillan, Basingstoke Enderwick P, Buckley PJ (2020) Rising regionalization: will the post-COVID-19 world see a retreat from globalization? Transnatl Corp J 27:99-111

Fairclough I, Fairclough N (2012) Political discourse analysis: a method for advanced students. Routledge, Abingdon and Oxon, New York, NY

Fairclough N (2010) Critical discourse analysis: the critical study of language, 2nd edn. Longman, Harlow

Fetzer A, Bull P (2012) Doing leadership in political speech. Discourse Soc 23:127-144. https://doi.org/10.1177/0957926511431510

Gjerde LEL (2021) Governing humans and 'things': power and rule in Norway during the Covid-19 pandemic. J Polit Power 0:1-21. https://doi.org/10.1080/ 2158379X.2020.1870264

Goffman E (1981) Forms of talk. University of Pennsylvania Press, Philadelphia

Hay C (1996) Narrating crisis. Sociology 30:253-277. https://doi.org/10.1177/ 0038038596030002004

Huber V (2020) Pandemics and the politics of difference: rewriting the history of internationalism through nineteenth-century cholera†. J Glob Hist 15:394-407. https://doi.org/10.1017/S1740022820000236

Jessop B (2013) Recovered imaginaries, imagined recoveries: a cultural political economy of crisis construals and crisis-management in the North Atlantic Financial Crisis Bob Jessop. In: Benner M(ed) Before and beyond the global economic crisis. Edward Elgar, Cheltenham

Klein J (2000) Komplexe topische Muster: Vom Einzeltopos zur diskurstypspezifischen Topos-Konfiguration. In: Schirren T, Ueding G (eds) Topik und Rhetorik. Niemeyer, Tübingen, pp. 623-649

Klein J (2019) Politik und Rhetorik: Eine Einführung. Springer Fachmedien, Wiesbaden

Kloet J, de, Lin J, Chow YF (2020) 'We are doing better': Biopolitical nationalism and the COVID-19 virus in East Asia. Eur J Cult Stud 23:635-640. https:// doi.org/10.1177/1367549420928092

Koller V (2012) How to analyse collective identity in discourse-textual and contextual parameters. In Crit Approaches Discourse Anal Discip 5, pp. 19-38

Koller V (2014) Applying social cognition research to critical discourse studies. In Hart C, Cap P (eds) Contemporary Critical Discourse Studies. Bloomsbury, London and New York, pp. 147-166

Koller V (2019) Gay rights as a symbol of ideological struggles between Russia and the West: A socio-cognitive discourse analysis. In: Berrocal M, Salamurović A (eds) Political Discourse in Central, Eastern and Balkan Europe. John Benjamins Publishing Company, Amsterdam, pp. 69-92

Kourachanis N, Lalioti V, Venieris D (2019) Social policies and solidarity during the Greek Crisis. Soc Policy Adm Int J Policy Res 678-692. https://doi.org/ $10.1111 /$ spol.12420

Kranert M (2019) Discourse and political culture. John Benjamins Publishing Company, Amsterdam

Kranert M (2017) 'Today I offer you, and we offer the country a new vision.' Discourse Soc 28:182-203. https://doi.org/10.1177/0957926516685463

Ledin P, Machin D (2018) Doing visual analysis: from theory to practice. SAGE Publications, London

Malešević S (2013) Nation-states and nationalisms: organization, ideology and solidarity. Polity, Cambridge

Malešević S (2020) Grounded nationalism. In: Palgrave Encyclopedia of Peace and Conflict. Palgrave, Basingstoke

Malm A (2020) Corona, climate, chronic emergency: War communism in the twenty-first century, First edition paperback. Verso Books, Brooklyn

Montessori NM (2016) CDA, Critical Events and Critical Event Studies: How to Make Sense of Critical Events in a Society of Radical Change. In: Lamond RI, Platt L (eds) Critical Event Studies. Palgrave Macmillan, London, pp. 131-148

Mühlhäusler P, Harré R (1990) Pronouns and people. Basil Blackwell, Oxford; Cambridge, USA

Munck GL (2009) Measuring democracy: a bridge between scholarship and politics/Gerardo L. Munck. Johns Hopkins University Press, Baltimore

Ozkirimli U (2020) Coronationalism? Even though coronavirus knows no borders, our solidarity often does.

Rajandran K (2020) 'A Long Battle Ahead': Malaysian and Singaporean Prime Ministers Employ War Metaphors for COVID-19. GEMA Onlinecircled R J Lang Stud 20:261-267. https://doi.org/10.17576/gema-2020-2003-15

Reisigl M (2008) Rhetoric of political speeches. In:Wodak R, Koller V (eds) Handbook of Communication in the Public Sphere. Mouton de Gruyter, Berlin, New York, pp. 243-270

Rosenberg CA (1989) What is an Epidemic? AIDS in Historical Perspective. Daedalus 118:1-17

Rothstein B (2017) Solidarity, diversity and the quality of government. In: The Strains of Commitment: The Political Sources of Solidarity in Diverse Societies, Banting, Keith; Kymlicka, Will. Oxford University Press. pp. 300-327

Skaaning S-E (2018) Different types of data and the validity of democracy measures. Polit Gov 6:105-116. https://doi.org/10.17645/pag.v6i1.1183 
Smith A (1998) Nationalism and modernism. Routledge, London Sontag S (1989) AIDS and its metaphors, 1st edn. Farrar, New York

Spencer L, Pahl RE (2006) Rethinking friendship: hidden solidarities today. Princeton University Press, Princeton

van Dijk TA (1998) Ideology: a multidisciplinary approach. Sage, London

van Dijk TA (2012) Knowledge, discourse and domination. In:Meeuwis M, Östman J-O (eds) Pragmaticizing understanding. John Benjamins Pub. Co., Amsterdam and Philadelphia, pp. 151-196

Wallaschek S (2020) The discursive construction of solidarity: analysing public claims in Europe's migration crisis. Polit Stud 68:74-92. https://doi.org/ $10.1177 / 0032321719831585$

Wengeler M, Ziem A (2014) Wie über Krisen geredet wird. Einige Ergebnisse eines diskursgeschichtlichen Forschungsprojekts: Einige Ergebnisse eines diskursgeschichtlichen Forschungsprojekts. Z Ft Für Lit Linguist 44:52-74

Wieczorek AE (2013) Clusivity: a new approach to association and dissociation in political discourse. Cambridge Scholars Publishing, Newcastle

Wittgenstein L, Anscombe GEM, Hacker PMS, Schulte J (2009) Philosophical investigations, Revised. 4th edn. by P.M.S. Hacker and Joachim Schulte. Wiley-Blackwell, Chichester

Woods ET, Schertzer R, Greenfeld L et al. (2020) COVID-19, nationalism, and the politics of crisis: a scholarly exchange. Nations Natl n/a:807-825. https://doi. org/10.1111/nana.12644

Wortham SEF (1996) Mapping participant deictics. J Pragmat 25:331-348. https:// doi.org/10.1016/0378-2166(94)00100-6

Zamponi L, Bosi L (2016) Which crisis? European Crisis and National Contexts in Public Discourse. Polit Policy 44:400-426. https://doi.org/10.1111/polp.12156

\section{Acknowledgements}

The authors would like to thank Carola Schoor for her help analyzing the speeches from the Netherlands and Belgium, and Thomas Walden for the competent copy-editing of the final version of the manuscript.

\section{Funding}

Open Access funding enabled and organized by Projekt DEAL.

\section{Competing interests}

The authors declare no competing interests

\section{Additional information}

Correspondence and requests for materials should be addressed to M.B.

Reprints and permission information is available at http://www.nature.com/reprints

Publisher's note Springer Nature remains neutral with regard to jurisdictional claims in published maps and institutional affiliations.

(c) (i) Open Access This article is licensed under a Creative Commons Attribution 4.0 International License, which permits use, sharing, adaptation, distribution and reproduction in any medium or format, as long as you give appropriate credit to the original author(s) and the source, provide a link to the Creative Commons license, and indicate if changes were made. The images or other third party material in this article are included in the article's Creative Commons license, unles indicated otherwise in a credit line to the material. If material is not included in the article's Creative Commons license and your intended use is not permitted by statutory regulation or exceeds the permitted use, you will need to obtain permission directly from the copyright holder. To view a copy of this license, visit http://creativecommons.org/ licenses/by/4.0/.

(c) The Author(s) 2021, corrected publication 2021 